\title{
HOUSTON, HOUSTON, DO YOU READ JAMES TIPTREE?
}

A way to pass the time.

\section{BY RACHAEL K. JONES}

A fter two hours of work, Daria got the space station's recycler back online without Hugh there to help her. If he had just waited 10 minutes while she tried resetting power. If he had let her double-check his gear before his spacewalk, like he was supposed to according to all the protocols.

\section{If. If. If.}

Now her only brother was drifting away from Station Mars One, a fragile floating bubble in the void. He brought to mind the time Daria packed her goldfish in the front seat for the drive to college. Glass bowl swathed in bubble wrap swathed in a blanket, set in a flimsy taped-up cardboard box. The thinnest sliver of shelter against a sudden end.

She pressed both palms into her eyeballs until stars blossomed, and with great effort, focused on her last obligation: to keep him company until he died.

The intercom crackled to life. "Your turn, Daria," said Hugh. He sounded weary, but in good spirits. Like they were still parked together with their e-readers in the control room, passing the long, boring hours caretaking the station until their six-month stint ended, and the relief shuttle arrived.

"The Martian Chronicles Ray Bradbury," she said after some thought. "Non-fiction. An alien visits Earth to write the definitive intergalactic biography of the science-fiction master." Hugh had taught her to play this game. You mashed up a novel title with its author, then invented a short synopsis.

"Ha. Not bad." He hummed to himself. "How about... Harlan Ellison's Watching Harlan Ellison? Comedy. Harlan's newest addiction is a reality $\mathrm{TV}$ series starring himself."

Four unbroken hours of this, and Hugh could still pull a laugh from her. "Lock In John Scalzi," Daria shot back. "Crime. The world's best prison architects match wits with a Hugo-winning escape artist who slips out of all restraints."

"Ha. Pretty good. But I said that one an hour ago," said Hugh. "Think of something different."

"Sorry. I suck at this game."

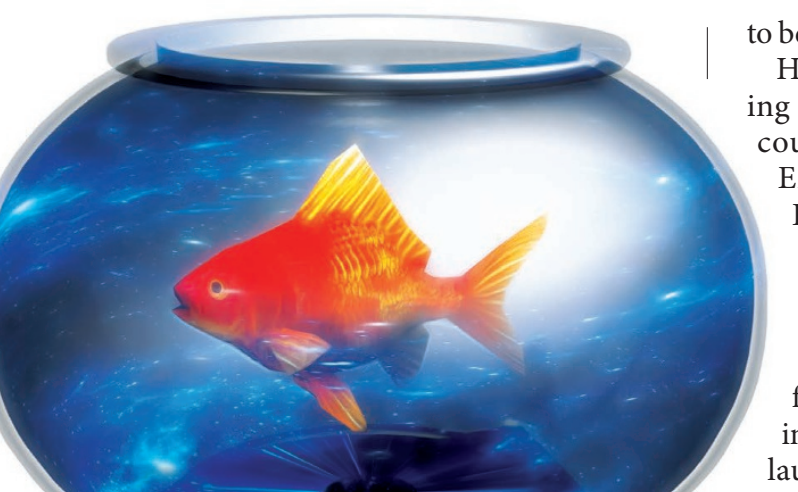

to be the man of everyone's dreams."

Hugh's belly laugh sent feedback squealing over the line. "Hey, we didn't say we could use anthologies! Good one, sis! Except you should've used Gardner Dozois. He invented this game. That would be hilarious."

Daria let the ringing laughter wash over her, and did not allow herself to flinch away from the sharp pain of the feedback. She wanted that sound burned into her synapses. He was humanity itself, laughing into the abyss as he hung suspended in his ridiculous, wonderful, bubblewrap suit, holding back the cold and dark, defeating the howling loneliness with the only weapon that ever worked.

"Hey, Daria? I'm getting tired," said Hugh. Six hours unmoored now. "But you've only got two months until the relief crew gets here. That's not so bad. You'll pass the time. You've got all those books."

Her resolve broke. Daria groped for her damaged spacewalk gear. Hugh had destabilized its joints when he turned it into a balloon for his birthday, but at least he wouldn't have to die alone. "I'll come and get you. You're not that far away. We can make it work somehow."

"No." It was so final, so firm. Her brother was never one to give orders. "Can't risk it. Someone has to be there to wake the relief crew from stasis when their shuttle arrives. Otherwise you'll lose more than Mars's worst prankster."

"Two Sisters Gore Vidal," she began. "It's about - about minotaurs - "

"I love you, okay?" His voice was definitely fainter. From weakness or distance, she couldn't say. Out the window, his body was just a suggestion against the bright dome of Mars, a word on the tip of the tongue.

"Remake Connie Willis!" she shouted. "Feed Mira Grant! The Sky That Laps Jay Lake!"

Daria called out into the void for a long time, shouting for her other half like a title missing its author, because without it, nothing made any sense.

She didn't want him to say it, to make real. "Best American Science Fiction and $\rightarrow$ NATURE.COM

Follow Futures: y @ NatureFutures f go.nature.com/mtoodm Fantasy John Joseph Adams. Erotica. A collection of sciencefiction shorts starring a sexbot programmed
Rachael K. Jones is an author, editor and secret android. Her fiction has appeared in dozens of magazines. She lives in Athens, Georgia, with her husband. 